\title{
Short Communication / Nota Científica New records of parasitized plants by Escobedia grandiflora (Orobanchaceae) in natural habitats
}

\author{
Edison Cardona Medina ${ }^{1,2,3}$ \& Sandra Bibiana Muriel Ruíz ${ }^{1}$
}

\begin{abstract}
Hemiparasitic plant roots adhere to neighboring plants in order to meet part or all of their nutritional requirements. Escobedia grandiflora (L. f.) Kuntze is a hemiparasitic plant found throughout the America. Its orange colored roots are used as a natural colorant in food and medicines, but there is little information about plant requirements. The aim of this study was to identify host plants of $E$. grandiflora in five natural habitats within the department of Antioquia (Colombia). There, E. grandiflora plants were selected and an area of $50 \times 50 \mathrm{~cm}$ around them was demarcated, in order to identify the vegetation in the quadrant with adhering haustoria. The Amount of haustoria of E. grandiflora on these plants was established. Twenty-two species belonging to seven botanical families were recorded as being parasitized by E. grandiflora, the most predominant family being Poaceae, with twelve species. Greater compatibility or preference was suggested for $18.2 \%$ of the identified plant species. It was concluded that $E$. grandiflora has a wide host range, especially within the Poaceae family. This record contributes to an increased knowledge of this species, and constitutes basic information for future studies.
\end{abstract}

Key words: Escobedia, parasitism, hosts, haustorium, Orobanchaceae.

\begin{abstract}
Resumen
Las plantas parásitas de raíces se adhieren a las plantas vecinas, absorbiendo vía xilema una parte o la totalidad de sus requerimientos nutricionales. Escobedia grandiflora es una planta hemiparasita obligada de raíces, que se encuentra en algunas regiones de América. Las raíces naranjadas de esta especie son usadas como colorante natural para los alimentos y en la medicina tradicional, pero existe poca información sobre esta planta parasita. El objetivo de este trabajo fue identificar las plantas hospederas de E. grandiflora en cinco hábitats naturales del departamento de Antioquia (Colombia). Para la identificación se ubicaron plantas de E. grandiflora, demarcadas en un área de $50 \times 50 \mathrm{~cm}$, revisando y verificando, a partir de la extracción de raíces de las plantas vecinas, la presencia de haustorios de color naranja adheridos, típicos de E. grandiflora. Se reporta la presencia de 22 especies dividas en 7 familias botánicas, siendo más predominante la familia Poaceae con 12 especies. Una mayor compatibilidad fue sugerida para el 18.2\% de las especies identificadas. Se puede concluir que $E$. grandiflora tiene un amplio rango de hospederos, especialmente dentro de la familia Poaceae. Este registro contribuye al incremento del conocimiento sobre la especie, y se constituye como una información básica para futuros estudios.
\end{abstract}

Palabras clave: Escobedia, parasitismo, hospederos, haustorio, Orobanchaceae.

Root hemiparasites adhere to neighboring plants, absorbing some or all of the water, carbohydrates, and minerals they require through the use of haustoria (Yoder 2001). A complex web of interactions is established between the parasitic plant and the host, affecting the structure of the entire community (Gibson \& Watkinson 1992b; Press \& Phoenix 2005). Successful parasitism depends on the ability of the parasitic plant to recognize and attack the host, the responses and

\footnotetext{
${ }^{1}$ Facultad de Ciencias Agrarias, Politécnico Colombiano Jaime Isaza Cadavid, Carrera 48 \# 7-151, Medellín, Antioquia, Colombia.

${ }^{2}$ Federal University of Santa Catarina, Centre for Agricultural Science, Rod. Admar Gonzaga 1346, 88034-000, Itacorubi, Florianópolis, SC, Brazil.

${ }^{3}$ Author for correspondence: cardonam33@gmail.com
} 
defense of the host, and the resource offering of the host for optimal growth of the parasite (Yoder 2001). Parasitic plants recognize a group of molecules liberated by their hosts, which act as stimulants for the germination of their seeds and the formation of haustoria. The amplitude of chemical compounds that a parasite can recognize determines its host specificity (Yoder 2001; Cardoso et al. 2011; Joel et al. 2011).

The family Orobanchaceae has the largest number worldwide of facultative and obligate parasites with approximately 87 genera and 1700 species, which are morphologically diverse and utilize a wide range of hosts (Westwood et al. 2010; Morawetz et al. 2010). Many genera of this family are known by their harmful effects on economically important plants, such a cropparasitic weed Striga hermonthica (Delile) Benth. (Bouwmeester et al. 2007; Parker 2009; Sholes \& Press 2008). Within this family, various genera are phylogenetically related to Escobedia, such as Alectra, Hyobanche, Striga, Melasma, Euphrasia, Parentucellia, Sopubia and Rhinanthus (Bennett \& Mathews 2006; Morawetz et al. 2010). The species of these genera have been found to parasitize plants of more than 18 families, among them: Andropogon monticola Roem. \& Schult., Andropogon pumilus Roxb., Arachis hypogaea L., Borreria pusilla (Wall.) DC., Commelina hasskarlii C.B. Clarke, Medicago sativa L, Oryza sativa L., Oryza glaberrima Steud., Panicum maximum Jacq, Paspalum scrobiculatum L., Pennisetum glaucum (L.)R. Br., Saccharum officinarum L, Sporobolus coromandelianus (Retz.) Kunth, Sorghum vulgare Pers., Vigna unguiculata (L.) Walp., Vigna radiata (L.) R. Wilczek, Tridax procumbens L., Zea mays L, among others hosts (Kumar \& Solomon 1941; Thombre 1962; Riches et al. 1992).

Escobedia grandiflora (L.f.) Kuntze is an obligate hemiparasitic plant (Cardona \& Muriel 2015) that has been used by tradional communities, especially in South America, due to its orange-colored roots that serve as a natural colorant for foods and medicine (Pennell 1931). Despite its importance, there is little information on this specie regarding aspects of its behavior as a parasitic plant. Cardona \& Muriel (2015) registered, under experimental conditions, the formation of haustoria of $E$. grandiflora in four plants of the Poaceae family: Zea mays, Andropogon bicornis L.. Calamagrostis viridiflavescens (Poir.) Steud. and Sporobolus jacquemontii Kunth. However, little was known so far about the host plants in its natural habitat, which allow it to reach its reproductive stage and thus maintain natural populations. The objective of this study was to determine the host plants of E. grandiflora in five previously identified natural habitats in the department of Antioquia.

The natural habitats in which Escobedia grandiflora was found were located in the countries of Copacabana $\left(6^{\circ} 18.781^{\prime} \mathrm{N}, 75^{\circ} 30.392^{\prime} \mathrm{W}\right)$, Gómez Plata $\left(7^{\circ} 9.566^{\prime} \mathrm{N}, 7^{\circ} 22.524^{\prime} \mathrm{W}\right)$, San Jerónimo $\left(6^{\circ} 22.40^{\prime} \mathrm{N}, 75^{\circ} 43.1^{\prime} \mathrm{W}\right)$, Yarumal $\left(7^{\circ} 9.458^{\prime} \mathrm{N}, 75^{\circ} 22.570^{\prime} \mathrm{W}\right)$ and Yolombó (6³4.871'N, 75'8.679'W) Antioquia-Colombia. For the determination of hosts, E. grandiflora was first located and an area of $50 \times 50 \mathrm{~cm}$ was demarcated around it in order to study the vegetation in the quadrant. A detailed revision of neighboring plants of E. grandiflora was done to verify whether they were parasitized or not (Gibson \& Watkinson 1992b). The revision entailed carefully uncovering the roots of neighboring plants by eliminating the soil around them until adhered orange colored haustoria were observed, following the methodology developed by Montes-Hernández et al. (2015). The number of haustoria in $10 \mathrm{~cm}$ of the root of the parasitized plant were counted of 30 hosts plants. If the number of haustoria were greater to or equal to 8 , they were ranked as high, with numbers oscillating between seven and three ranked as medium, and less than three ranked as low. Later, botanical samples of parasitized species were collected for identification. When the plants were not fertile, specimens were collected and grown in greenhouse bags at the Laboratory of Botany and Vegetal Physiology of the Politécnico Colombiano Jaime Isaza Cadavid until they became fertile. Samples of the plants were identified at the JUAM, UDEA, and COL herbaria.

Twenty-two hosts belonging to seven botanical families, of which $52.3 \%$ of the parasitized species belonged to the family Poaceae, including three specimens of Axonopus. 14\% of the species belonged to the family Asteraceae; $9 \%$ to the family Cyperaceae with two species of Scleria; and $9 \%$ to the family Melastomataceae, with two species of the genus Clidemia. The families Thelypteridaceae, Blechnaceae, and Bromeliaceae were each represented, with $1 \%$ of the parasitized species. In Table 1, there is a complete list of parasitized species and abundance of haustoria of E. grandiflora found in their roots (Fig. 1a-d). 

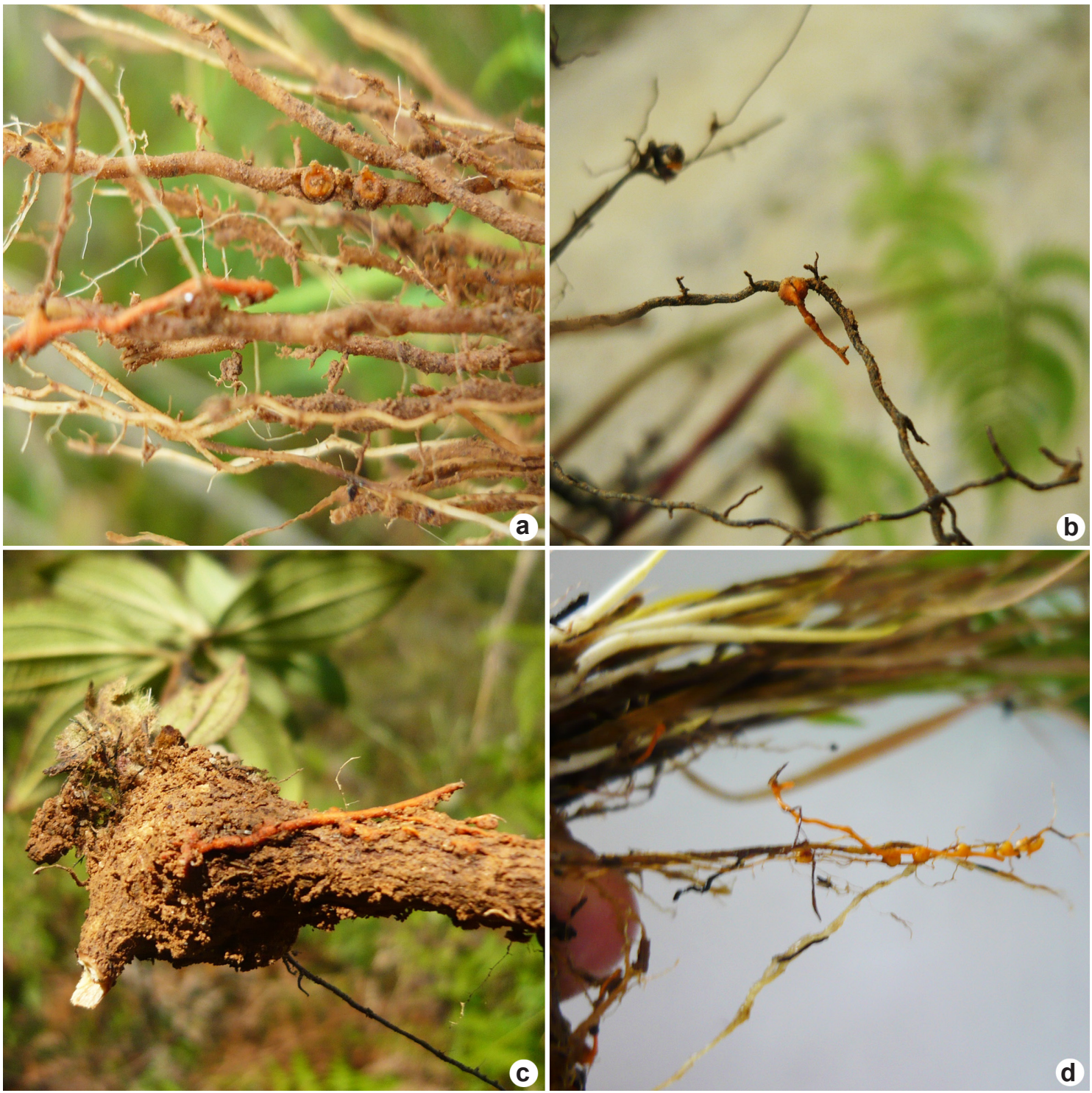

Figure 1 - The haustoria of E. grandiflora on roots - a. Axonopus compressus; b. Thelypteris conspersa; c. Clidemia strigillosa; d. Calamagrostis viridiflavescens.

The predominance of hosts in the family Poaceae was also registered for plant parasites of the Striga and Sopubia genera (Kumar \& Solomon 1941; Thombre 1962). Here, in $31.8 \%$ of the parasitized species, low numbers of haustoria were observed, which may indicate a low compatibility with, or preference of E. grandiflora for these species. A medium number of haustoria were found in $50 \%$ of the species, while $18.2 \%$ had a high number of haustoria. These last belonged in their totality to Poaceae, suggesting that E. grandiflora has a preference for, or more marked compatibility with, plants of this family. Which may suggest that it has a better compatibility with family Poaceae (Fig. 1d). Many of the species registered as hosts in this study were observed in the same natural habitats within the department de Antioquia, for which it is possible for E. grandiflora to form simultaneous parasitic relationships, as is registered in other species of the family Orobanchaceae (Gibson \& Watkinson 1989a). This is the first study comprising the identification of hosts of the hemiparasite $E$. grandiflora, knowledge of which is increasing and constitutes base information for future studies related 
Table 1 - Host plants of E. grandiflora in five municipalities of Antioquia, Colombia.

\begin{tabular}{|c|c|c|c|}
\hline & Specie & Family & Number of haustoria \\
\hline 1 & Andropogon bicornis & Poaceae & Middle \\
\hline 2 & Axonopus compressus & Poaceae & High \\
\hline 3 & Axonopus scoparius (morfotipo 1) & Poaceae & Middle \\
\hline 4 & Axonopus scoparius (morfotipo 2). & Poaceae & Low \\
\hline 5 & Calamagrostis viridiflavescens & Poaceae & Middle \\
\hline 6 & Cenchrus c.f purpureus & Poaceae & High \\
\hline 7 & Hyparrhenia rufa & Poaceae & Middle \\
\hline 8 & Melinis minutiflora & Poaceae & Middle \\
\hline 9 & Paspalum sp. & Poaceae & High \\
\hline 10 & Sporobolus jacquemontii & Poaceae & Middle \\
\hline 11 & Trichanthecium cf. polycomum & Poaceae & High \\
\hline 12 & Urochloa decumbens & Poaceae & Low \\
\hline 13 & Calea sessiliflora & Asteraceae & Middle \\
\hline 14 & Lepidaploa canescens & Asteraceae & Low \\
\hline 15 & Taraxacum officinale & Asteraceae & Low \\
\hline 16 & Scleria sp. & Cyperaceae & Middle \\
\hline 17 & Scleria distans & Cyperaceae & Low \\
\hline 18 & Clidemia sericea & Melastomataceae & Middle \\
\hline 19 & Clidemia strigillosa & Melastomataceae & Middle \\
\hline 20 & Thelypteris conspersa & Thelypteridaceae & Middle \\
\hline 21 & Blechnum cordatum & Blechnaceae & Low \\
\hline 22 & Pitcairnia sp. & Bromeliaceae & Low \\
\hline
\end{tabular}

to its requirements for reaching reproduction, its conservation, and the feasibility of its sustainable use.

\section{Acknowledgements}

The authors would like to thank the Politécnico Colombiano Jaime Isaza Cadavid and COLCIENCIAS (convocation 693 for young investigators) for their financial support; the JUAM, UDEA, and COL herbaria, and especially D.A. Giraldo for the identification of plants in the family Poaceae; H. David, F.J. Roldán and N. López for the identification of the other species; $\mathrm{S}$. Montoya, D. Arcos, J.C. Zapata, and J.C. Ramírez for their support during fieldwork.

\section{References}

Bennett, J.R. \& Matthews, S. 2006. Phylogeny of the parasitic plant family Orobanchaceae inferred from phytochrome A. American Journal of Botany 93: 1039-1051.
Bouwmeester, H.J.; Roux, C.; Lopez-Raez, J.A. \& Becard G. 2007. Rhizosphere communication of plants, parasitic plants and AM fungi. Trends in Plant Science 12: 224-230.

Cardona, E. \& Muriel, S.B. 2015. Seed germination and plant development in Escobedia grandiflora (Orobanchaceae): evidence of obligate hemiparasitism? Acta Biológica Colombiana 20: 133-140. DOI: <http://dx.doi.org/10.15446/abc. v20n2.43776>.

Cardoso, C.; Ruyter-Spira C. \& Bouwmeester H.J. 2011. Strigolactones and root infestation by plant-parasitic Striga, Orobanche and Phelipanche spp. Plant Science 180: 414-420.

Gibson, C.C. \& Watkinson, A.R. 1989. The host range and selectivity of a parasitic plant: Rhinanthus minor L. Oecologia 78: 401-406.

Gibson, C.C. \& Watkinson A.R. 1992. The role of the hemiparasitic annual Rhinanthus minor in determining community structure. Oecologia 89 : 62-68. 
Joel, D.M.; Chaudhuri, S.K.; Plakhine, D.; Ziadna, H. \& Steffens J.C. 2011. Dehydrocostus lactone is exuded from sunflower roots and stimulates germination of the root parasite Orobanche cumana. Phytochemistry 72: 624-634.

Kumar, L.S.S. \& Salomon S. 1941. A list of hosts of some phanerogamic root-parasites attacking economic crops in India. Proceedings of the Indian Academy of Sciences - Section B 55: 233-238.

Montes-Hernández, E.; Sandoval-Zapotitla, E.; Bermúdez-Torres, K. \& Trejo-Tapia, G. 2015. Potential hosts of Castilleja tenuiflora (Orobanchaceae) and characterization of its hasutoria. Flora 214: 11-16.

Morawetz, J.J.; Randle, C.P. \& Wolfe, A.D. 2010. Phylogenetic relationships within the tropical clade of Orobanchaceae. Taxon 59: 416-426.

Parker, C. 2009. Observations on the current status of Orobanche and Striga problems worldwide. Pest Manag Sci 65: 453-459.

Pennell, F.W. 1931. Escobedia: A neotropical genus of the Scrophularlaceae. Proceedings of the
Academy of Natural Sciences of Philadelphia 83: 411-426.

Press, M.C. \& Phoenix, G.K. 2005. Impacts of parasitic plants en natural communities. New Phytologist 166: 737-751.

Riches, C.R.; Hamilton, K.A. \& Parker C. 1992. Parasitism of grain legumes by Alectra species (Scrophulariaceae). Annals of Applied Biology 121: 361-370.

Sholes, J.D. \& Press, M.C. Striga infestation of cereal crops - an unsolved problem in resource limited agricultura. Current Opinion in Plant Biology 11: 180-186.

Thombre, M.V. 1962. Some new hosts of Striga and Sopubia. Proceedings of the Indian Academy of Sciences - Section B 55: 233-238.

Westwood, J.H.; Yoder, J.I.; Timko, M.P. \& Depamphilis C.W. 2010. The evolution of parasitism in plants. Trends in Plant Science 15: 227-235.

Yoder, J.I. 2001. Host-plant recognition by parasitic Scrophulariaceae. Current Opinion in Plant Biology 4: 359-365. 